\title{
Design and Development of Manual Multicrop Planter
}

\author{
Vajrala Narendra Reddy*, K. Yaswanth Kumar, S. C. Moses and R. N. Aalam \\ Department of Farm Machinery and Power Engineering, Vaugh Institute of Agricultural \\ Engineering and Technology (VIAET), Sam Higginbottom University of Agriculture, sciences \\ and Technology, (SHUATS) Prayagraj, (Uttar Pradesh), India \\ *Corresponding author
}

\section{A B S T R A C T}

\section{Ke ywords \\ Developed, Manual, Multicrop planter \\ Article Info \\ Accepted: \\ 08 December 2020 \\ Available Online: \\ 10 January 2021}

The developed manual multicrop planter helps to small and marginal farmer's. It is manufactured by local available material to decrease cost of planter. The recommended row to row spacing, seed rate, seed to seed spacing and depth of seed placement vary from crop to crop and for different agro-climatic conditions to achieve optimum yields. The designed manual multi-crop planter had handle, wheels, adjustable furrow opener and furrow closer, seed hopper, seed metering house. The planter has adjustable furrow opener and soil covering device. The planter can be used for different crops by changing the seed metering wheel. The planter is a pulling type, The total cost of planter is Rs.5270. The manual multi-crop planter was simple in design and easily operated by a single worker (men/women).

\section{Introduction}

Manual method of sowing seed is a time, high seed rate, labour consuming process. The disadvantage of manual method is seed requirement is more, row to row and seed to seed distance is not uniform results in gaps in germination. Due to this soil moisture content is not maintained and inter-culturing not possible. As our population continues to increase, it is necessary that we must produce more food, but this can only achieved through some level of mechanization. The use of hand tools for land cultivation is still largest in India because draft animals and tractors require resources that many Indian farmers do not have easy access to. Farm mechanization reduce human muscle in all forms and at any level of complexity in agricultural production , processing storage and so on in order to reduce dullness and drudgery, improve timeliness and efficiency of various farm operations. Sowing is on of the important agricultural operations for raising crops, proper application of fertilizer at proper location has also a good effect on crop growth and yield. The basic difference between seed drill and planter is that a seed drill sows seeds in at specified rate and at the proper depth and in rows, while planter can deposit seeds at a specified rate in hills and row spaced to permit inter row cultivation and also function 
as a seed drill if required. Based on the above problems the simple and low cost planter id developed. It can be operated by a single worker and reasonable to small farmers.

Nandini, et, al. (2018) A manually operated multi crop inclined plate planter was designed and its performance evaluated for planting of Maize, Pigeon pea, Bengal gram, Green gram. Power was transmitted from the drive wheel to metering mechanism through chain and multi sprockets and bevel gears. Inclined plate type metering mechanism was used in the planter. Seeds were placed in the furrows at desired depth and seed to seed spacing through adjustable system. The average Depth of Maize, Pigeon Pea, Bengal gram and Green gram was $4.6,3.83,4.17$ and $4.21 \mathrm{~cm}$ and seed to seed spacing was $22.7,19.2,12.6$ and $11.47 \mathrm{~cm}$ respectively. The multi crop planter at an average forward speed of $2.7 \mathrm{~km} . \mathrm{h}-1$ for planting Maize, Pigeon Pea, Bengal gram and Green gram and field efficiency for Maize, Pigeon Pea, Bengal gram. The handle was designed adjustable for the different height of person women and men which can adjust according to own height which reduced drudgery. The adjustable handle helps the operator to push the planter at the time of operation. The adjustable handle length was a $148 \mathrm{~cm}$ and $40 \mathrm{~cm}$ of mild steel round bar was bolted inside of the hallow M.S pipe. The cost of the manually operated multi crop planter was approximately rupees 4460 this is the within buying capacity of the formers of the India.

Tapan Khura et, al. (2018) design and developed a manually operated gladious planter was pulled by two persons as a power source and guided by a person. The coefficient of variation and highest deviation from the mean spacing was observed as $12.93 \%$ and $2.65 \%$ respectively. The maximum coefficient of uniformity of $90.59 \%$ was observed for a nominal corm spacing of $15 \mathrm{~cm}$ at $0.56 \mathrm{~km} / \mathrm{hr}$ forward speed. An average miss percentage was observed as 2.65 and 2.25 for nominal corm spacing of 15 and $20 \mathrm{~cm}$. The multiple indexes were zero for two levels corm spacing and forward speed of operation. The QFI was found in the range of 97.2 and 97.9 percent. The average field capacity of the planter was observed as $0.02 \mathrm{ha} / \mathrm{hr}$. the average draft requirement of the planter was found as $821+50.3$ or $821-50.3 \mathrm{~N}$.

Osadare and Manuwa (2019) a pulse planter was designed and evaluated for no-till conditions. It has the capability of delivering the seeds precisely with uniform depth in the furrow at uniform spacing between the seeds. The planter is incorporated with a coulter to cut residue and threshes on the soil after cleaning. The drive shaft of the planter control's the speed plate shaft through the aid of a bevel gear. The results obtained from the trail tests showed that the planter functioned properly with a seed rate of $0.96 \mathrm{~kg} / \mathrm{h}$. The average seed spacing for field test is $28.6 \mathrm{~cm}$ and the average percentage of seed damage is 6.84. The field efficiency of $76.8 \%$ and average field capacity of $0.67 \mathrm{ha} / \mathrm{h}$ were obtained from the test.

Mohammed issac et al. (2020) developed and evaluated manually operated single-row maize planter was as attributed to the speed of the human pushing. Therefore, it is recommended that the speed of running the seed planter be reduced to obtain the desired spacing. The majority of the holes (making up $37.8 \%$ of the experimented holes) contained 2 seeds while the least (making up $4.4 \%$ of the experimented holes) contained 5 seeds. The seed planter has a seed rate per hectare of $73,162.84$ seed rate/hectare, and the weight of maize grain required per hectare was found to be $21.82 \mathrm{~kg} / \mathrm{hectare}$ which is between the specified seed planter range. 


\section{Materials and Methods}

The planter was developed in the workshop. Department of Farm Machinery and Power Engineering, Vaugh school of Agricultural engineering and Technology, Sam Higginbottom institute of Agriculture, Technology and sciences, Prayagraj. The materials and methods used in the studies discussed below:

Machine tools used for development of manual multicrop planter

\section{Design considerations}

Power developed by the operator of machine

Power of useful work done by an average human on the machine is given by (Campbell, 1990)

$\mathrm{HP}=0.35-0.092 \log \mathrm{t}$

Where, $\mathrm{T}=$ operation time in minutes.

\section{Design of the size of the planter}

For the design of the planter, first of all we design furrow opener for the sowing of seeds, so

Number of furrow opener in the planter

(Z) $=\frac{\text { draft of planter (D)kgf }}{\text { draftof each rowv(dr) }}$

\section{Working width of the planter}

$(\mathrm{W})=\mathrm{Z} \times$ row to row distance (depend on crop types)

\section{Design of seed hopper}

Volume of seed hopper $\left(\mathrm{V}_{\mathrm{b}}\right)=1.1 \mathrm{~V}_{\mathrm{s}}$

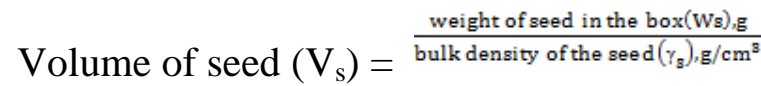

$\mathrm{V}_{\mathrm{b}}=1.1^{\frac{\mathrm{w}}{\mathrm{w}_{\mathrm{s}}}}$

Where, $\mathrm{W}_{\mathrm{s}}=$ weight of seed in the box, $\mathrm{g}$

$\gamma_{s}=$ bulk density of seeds, $\mathrm{g} \mathrm{cm}^{3}$

$\mathrm{V}_{\mathrm{b}}=$ volume of seed box, $\mathrm{cm}^{3}$

$\mathrm{V}_{\mathrm{s}}=$ volume of seed, $\mathrm{cm}^{3}$

\section{Power transmission system of manual} multi-crop planter

The planter was operated by manually to make it cost effective. Power is transmitted from the transport wheel to the seed metering wheel through roller chain. Since a power(HP) transmitted in manual seed planter is very low. So, for the amplification of the power for desired power requirement of seed metering wheel, we apply a chain sprocket system which have two chain sprockets (small sprocket have 12 teeth and large sprocket have 18 teeth). The chain length is calculated by the following equation.

$\mathrm{m}=\frac{\mathrm{zc}}{\mathrm{p}}+\frac{\mathrm{z}_{1+\mathrm{z}_{2}}}{2}+\frac{\left(\mathrm{z}_{2}-\mathrm{z}_{1}\right)^{2}}{2 \pi \mathrm{p}}$

Where,

$\mathrm{m}=$ no of chain links

$\mathrm{C}=$ centre to centre distance between two sprockets, $\mathrm{mm}$

$\mathrm{P}=$ is the chain pitch, $\mathrm{mm}$

$\mathrm{Z}_{1}$ and $\mathrm{Z}_{2}$ are the number of teeth in the driver sprocket and driven sprocket respectively.

\section{Length of chain (mm)}

$\mathrm{L}_{\mathrm{c}}=\mathrm{m} \times \mathrm{p}$

Where, $\mathrm{L}_{\mathrm{c}}=$ chain length, $\mathrm{mm}$

$\mathrm{m}=$ number of chain links

$\mathrm{p}=$ chain pitch, $\mathrm{mm}$ 


\section{Results and Discussion}

\section{Frame}

The frame of manually operated multicrop planter was including handle, wheels and main shaft, Where all the other components of planter were mounted. The two design factors were considered in the determination of the material required for the frame and strength.

\section{Handle}

The handle of manually operated multicrop planter was designed adjustable for the different height of person male or female which can adjust according to own height which reduce drudgery. The materials was used for handle is $3.5 \mathrm{~cm}$ diameter of mild steel cylindrical pipe length $102 \mathrm{~cm}$ and 2.5 $\mathrm{cm}$ diameter, $162 \mathrm{~cm}$ length cylindrical pipe was attached to hold operated body.

\section{Main shaft}

The shaft is mainly subjected to bear the loads and to resist moments caused the other parts in the equipment. The length of the shaft is $46 \mathrm{~cm}$ with diameter of $1.6 \mathrm{~cm}$. The shaft having bush to tighten and correct fitting of a furrow opener. The material used for the design mild steel.

\section{Seed Metering Wheel Shaft}

It rotates the seed metering wheel and have ball bearing at the both end of the shaft. The length and diameter of seed metering wheel shaft was $240 \mathrm{~mm}$ and $20 \mathrm{~mm}$ respectively. The material was used for the design mild steel.

\section{Wheels}

Two wheels were designed of manually operated planter. The wheels were designed with lugs on its periphery which improve the better traction and reduced slippage at the time of planting. The larger sprocket was attached to main shaft and rotated by a two wheels. When a human pull the planter, wheels were rotates and transfer the power large sprocket to small sprocket with the help of chain, in such a way seed metering wheel rotate, seed was singulated into the cell and dropped into the planting opener with the seed discharge tube that deposits the seed in the soil. The diameter of both wheel of manual operated planter was $340 \mathrm{~mm}$ and material used for design was mild steel flat bar width $2 \mathrm{~cm}$

\section{Wheel lugs}

The wheel lugs was designed in rectangular shape. The function of lugs on wheels in manual multicrop planter to increase the traction and reduced wheel slippage at the time of operation. The length, width, thickness and number of lugs were 50, 20, $5 \mathrm{~mm}$ and 24 respectively. The material used for the design was mild steel flat bar.

\section{Seed metering mechanism}

Seed metering mechanism is placed at the bottom of the box. The mechanism which picks up seeds from the box and delivers them in to the seed tube is called seed metering mechanism.

\section{Cell feed mechanism}

It is mechanism in which seeds are collected and delivered by a series of equally spaced cells on the periphery of a circular plate or wheel. The wheel has ten numbers of cells for chickpea crop.

Power transmission: The power can be transmitted to seed metering device through ground wheel by chain and sprocket. Chain 
drive consists of endless chain whose links engage the teeth of sprockets keyed to the shafts of driving and driven mechanisms. The basic function of a chain is to transmit power and to synchronize motion or maintain a fixed speed ratio between rotating shafts. In this roller chain is used for easy availability and low cost.

\section{Roller chai}

It is made up of alternative roller links and pin links with pins. The bushings are free to turn. Roller chains are used where there is heavy loads at low speeds between shafts that are far apart. The number of links in chain was 43, length of link is $1.4 \mathrm{~cm}$. The length of chain is $60 \mathrm{~cm}$.

Table.1 Machine and tools used for development of manual multicrop planter

\begin{tabular}{|l|l|l|}
\hline S.No & Machine/ Tool & Purpose \\
\hline $\mathbf{1}$ & Drill machine & Hole making \\
\hline $\mathbf{2}$ & Lathe machine & Cutting/Finishing/Shaping/Threading \\
\hline $\mathbf{3}$ & Grinding machine & Grinding/Cutting tool \\
\hline $\mathbf{4}$ & Cutting blade & Cut flat bar \\
\hline $\mathbf{5}$ & Manual facing lathe machine & Making ground wheel \\
\hline $\mathbf{6}$ & Round file & Smooth rough edges \\
\hline $\mathbf{7}$ & Electric welding machine & Welding \\
\hline $\mathbf{8}$ & Steel tape & Measurement of linear distance \\
\hline $\mathbf{9}$ & Vernier calipers & Measurement of inner and outer diameter \\
\hline $\mathbf{1 0}$ & Centre punch & Hole making \\
\hline $\mathbf{1 1}$ & Hammer & Used to strike an object \\
\hline $\mathbf{1 2}$ & Scissors & Cutting sheet metal \\
\hline $\mathbf{1 3}$ & Vice & Clamping or holding \\
\hline $\mathbf{1 4}$ & Spanner & Tighten nut and bolt \\
\hline
\end{tabular}

Table.2 Specifications of the Manual multicrop planter

\begin{tabular}{|l|l|l|l|}
\hline S.No & Parameter & Specifications & Material \\
\hline $\mathbf{1}$ & Length & $102 \mathrm{cms}$ & \\
\hline $\mathbf{2}$ & Width & $48 \mathrm{cms}$ & \\
\hline $\mathbf{3}$ & Height & $168 \mathrm{cms}$ & Mild steel \\
\hline $\mathbf{4}$ & Furrow opener & Shoe type, 4cm diameter & Mild steel \\
\hline $\mathbf{5}$ & Ground wheel & $34 \mathrm{~cm}$ diameter & Plastic \\
\hline $\mathbf{6}$ & Seed metering device & $\begin{array}{l}\text { Cell feed }, 10 \mathrm{~cm} \text { diameter, 10 } \\
\text { cells on device }\end{array}$ & GI Steel \\
\hline $\mathbf{7}$ & Seed hopper & $\begin{array}{l}25 \mathrm{~cm} \text { length, 19cm height and } \\
25 \text { width }\end{array}$ & Mild steel \\
\hline $\mathbf{8}$ & Seed tube & 34 & \\
\hline $\mathbf{9}$ & Power transmission & Chain and sprocket & \\
\hline $\mathbf{1 0}$ & Transmission ratio & $1.5: 1$ & $13 \mathrm{Kg}$ \\
\hline $\mathbf{1 1}$ & Weight & & \\
\hline
\end{tabular}


Fig.1 View of developed manual multicrop planter

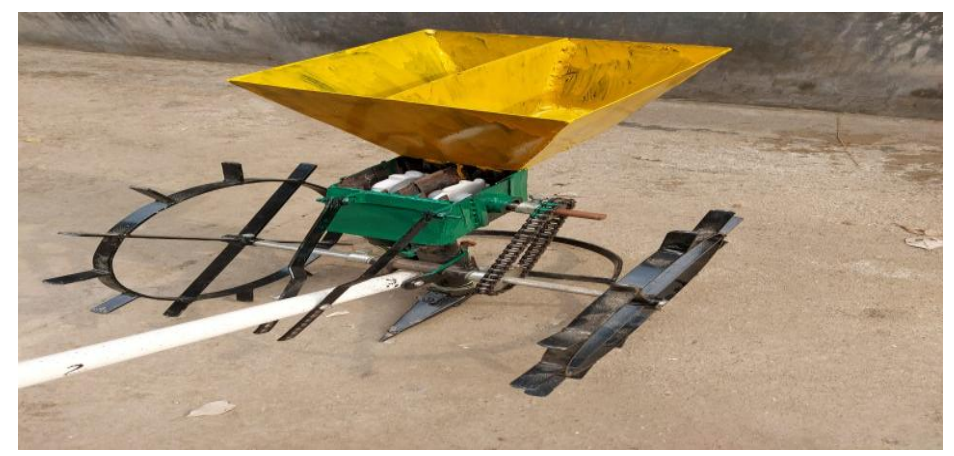

\section{Sprocket}

The larger sprocket was fixed on ground wheel shaft. Which transfer the power, drive wheel to small sprocket which was attached seed metering wheel shaft with the help of roller chain. Power transmission was done by the larger sprocket and roller chain. The number of teeth in larger sprocket and small sprocket was 18 and 12 respectively. The sprockets have bush's to fit on shaft and tighten with bolt, so they cannot freely move on shaft while working on field

\section{Seed hopper}

The amount of seed contained depends upon the size of the seed hopper. The shape of hopper was designed at the top. The volume of seed hopper was $9000 \mathrm{~cm}^{3}$. The height bottoms to top of seed hopper were $250 \mathrm{~mm}$ $250 \mathrm{~mm}$ square at top. To obtain free flow of seeds, the slope of the hopper was fixed, which is modestly higher than the average angle of repose of the seeds. The material was used for design $1 \mathrm{~mm}$ thickness mild steel metal sheet for low cost and light weight.

\section{Seed metering wheel house}

The grins are dropped from hopper to feed to box. It contains a seed metering mechanism to deliver the seeds from feed box to furrow opener tube or delivery tube. The feed length
$11 \mathrm{~cm}$, width $11.5 \mathrm{~cm}$, height $11 \mathrm{~cm}$. The shape of the feed box is rectangular shape for easy construction.

\section{Furrow opener}

The furrow opener of manually operated multicrop planter was designed adjustable varies to suit the soil conditions of particular region. The depth of sowing various seeds control by the adjustable furrow opener (figure no 3.9). Shoe type furrow opener was designed. Adjustable furrow opener permits planting at each variety's ideal ground depth. These types of furrow openers was used for forming narrow slit under heavy soils for placement of seeds at desired depths. The material used for the design was $40 \mathrm{~mm} \mathrm{x}$ $5 \mathrm{~mm}$ mild steel flat bar.

\section{Soil covering device}

The $\mathrm{C}$ type soil covering device of multicrop planter was designed adjustable. It was designed to allow for proper covering and compaction of the soil over the seeds in the furrows. The materials used for design was $40 \mathrm{~mm} \times 5 \mathrm{~mm}$ mild steel flat bar.

\section{Cost estimation}

The total cost of developed manual multicrop planter was Rs. 5270. 
In conclusion the manual multicrop planter was fabricated simple in design and made of locally available materials. The equipment operation is smooth and easily operated by a single worker (male/female). The manual multicrop planter has another advantage of it is easily dismantle and transportable by a single person. The cost of equipment was low affordable by marginal and small farmers. So, the overall performance of manual multicrop planter was satisfactory.

\section{Acknowledgment}

The author is thankful to Professor Dr. S. C. Moses, Department of Farm Machinery and Power Engineering, Vaugh Institute of Agricultural Engineering and Technology (VIAET), Sam Higginbottom University of Agriculture, sciences and Technology, (SHUATS) Prayagraj, (Uttar Pradesh).

\section{References}

Ani, O. A., B. B. Uzoejinwa and N. F. Anochili. 2016. Design, Construction and evaluation of a vertical plate maize seed planter for gardens and small holder faormers. Vol. 35, No. 3.

Malik, A. U., M. Ahmad alias H. A. Bukhsh and I. Hussain"Effect of seed Rates sown on different Dates on Wheat under Agro- Ecological conditions of Dera Ghazi Khan" The journal of Animal \& Plant sciences 19(3):2009 pp:126-129.

Ramesh, D. and H. P. Girishkumar, "Development of Agriculture Seeding Equipment", International Journal of Informative \& Futuristic Research, 2014, Volume -1 Issue -10, J, Pp-133138.

Srigiri D., et al., (2016) Development of Single Row Manually Operated Multi Crop Planter. International Journal of Agriculture Sciences, ISSN: 09753710 \& E-ISSN: 0975-9107, Volume 8, Issue 30, pp.-1632-1634.

Vinod Kumar, Vijaya Rani, Mukesh Jain, Anil Kumar, Sushil Kumar and Naresh. 2018. Design of 'Anjul' Seed Metering Mechanism for Round Seeds and its Seed Pattern Characteristics. Int.J.Curr.Microbiol.App.Sci. $\quad$ 7(03): 1536-1543.

\section{How to cite this article:}

Vajrala Narendra Reddy, K. Yaswanth Kumar, S. C. Moses and Aalam, R. N. 2021. Design and Development of Manual Multicrop Planter. Int.J.Curr.Microbiol.App.Sci. 10(01): 545-551. doi: https://doi.org/10.20546/ijcmas.2021.1001.066 